\title{
Optimalisasi Penggunaan Software Zoom dan Google Meet Dalam Meningkatkan Efektifitas Pembelajaran Daring
}

\author{
Mesran $^{1,}$, , Surya Darma Nasution ${ }^{1}$, Suginam ${ }^{2}$, Joli Afriany ${ }^{3}$, William Ramdhan ${ }^{4}$ \\ 1 Prodi Teknik Informatika, Universitas Budi Darma, Medan, Indonesia \\ 2 Prodi Manajemen Retail, Universitas Budi Darma, Medan, Indonesia \\ ${ }^{3}$ Universitas Nahdlatul Ulama Sumatera Utara, Medan, Indonesia \\ ${ }^{4}$ Prodi Sistem Informasi, STMIK Royal Kisaran, Kisaran, Indonesia \\ Email: 1,*mesran.skom.mkom@gmail.com, ${ }^{2}$ surya.darma.nasution1@gmail.com, ${ }^{3}$ suginam.icha@gmail.com, \\ 4joliafriani@gmail.com, ${ }^{5}$ william.ramdhan052@gmail.com
}

\begin{abstract}
Abstrak-Pembelajaran daring atau pembelajaran yang dilakukan secara online dapat dilakukan dengan bantuan dan dukungan sebuah aplikasi sebagai penghubung antara pendidik dan para peserta didik. Banyak tenaga pendidik yang masih awam terhadap penggunaan teknologi maupun aplikasi hal itu dianggap sebagai gaptek teknologi sehingga sudah menjadi tugas dan tanggung jawab dosen ilmu komputer memberikan pengajara dan transfer ilmu terhadap pengetahuan dalam penggunaan teknologi dan aplikasi dalam membantu pembelajaran daring. Dilakukan pemberian transfer ilmu penetahuan oleh dosen-dosen kepada tenaga pendidik lainnya dalam bentuk workshop, pada pembelajaran ini menggunakan software Zoom dan Google Meet dalam meningkatkan efektifitas pembelajaran daring. Software Zoom dan Google Meet merupakan sebuah software yang paling banyak digunakan dan memiliki keunggulan dalam penggunaannya. Pembelajaran yang diajarkan dalam bentuk workshop kepada peserta tenaga didik diharapkan mampu meningkatkan efektifitas pembelajaran.
\end{abstract}

Kata Kunci: Workshop; Zoom; Google Meet

Abstract-Online learning or online learning can be done with the help and support of an application as a liaison between educators and students. Many educators who are still unfamiliar with the use of technology and applications, it is considered a technological gap, so it has become the duty and responsibility of computer science lecturers to provide teaching and knowledge transfer to knowledge in the use of technology and applications in assisting online learning. The transfer of knowledge was carried out by lecturers to other educators in the form of workshops, in this learning using Zoom and Google Meet software in increasing the effectiveness of online learning. Zoom and Google Meet software are the most widely used software and have advantages in their use. Learning that is taught in the form of workshops to students is expected to increase the effectiveness of learning.

Keywords: Workshop; Zooms; Google Meet

\section{PENDAHULUAN}

Pembelajaran secara online sudah diterapkan sebelum terjadi pandemi covid-19. Diterapkan pembelajaran online dianggap karena mampu meningkatkan efektifitas pembelajaran karena proses pembelajaran online tidak bergantung kepada tempat dan waktu secara mengikat. Biasanya sekolah international dan kampus bebas/merdeka menerapkan sistem pembelajaran online. Saat ini pebelajaran daring dianggap wajib dilakukan karena adanya pandemic covid-19 karena proses pembelajaran secara langsung dianggap berbahaya terhadap tingkat keselamatan dan kesehatan peserta didik dan tenaga pendidik, tingkat bahaya terhadap kesehatan dimasa pandemi sudah menyita perhatian dunia (Syarifuddin et al. 2020).

Tingginya tingkat penularan terhadap virus covid 2019 yang dapat berdampak kepada kematian mengakibatkan banyak negara yang sangat waspada dan antisipasi terhadap penyakit ini, mudahnya proses penularan mulai dari kontak pisik, cipratan air liur pasien terkontaminasi dan juga pasien saat tertular banyak pasien yang tidak terlihat memiliki gejala sehingga mudah menyebarkan kepada orang lain saat sedang berinteraksi dengan masyarakat sekitar. Hal tersebut membuah membuat banyak negara memberlakukan lockdown yaitu melarang masyarakatnya untuk terlalu banyak beraktivitas diluar ruangan, melakukan penerapan protokol kesehatan, menjaga jarak sehingga seluruh aktivitas yang mengundang keramaian akan dibubarkan. Salah satu keramaian yang paling umum merupakan kegiatan yang beresiko tinggi seperti perkumpulan di suatu mall yang padat, pelayanan pemerintahaan, sekolah dan perguruan tinggi (Yunus and Rezki 2020).

Pada masa pandemic sistem pendidikan dirubah menjadi pembelajaran jarak jauh atau lebih dikenal dengan sistem daring, keuntungan dari sistem daring ini bebas terhadap ruang, dan tidak perlu melakukan perkumpulan, pembelajaran menjadi lebih fleksibel dan mudah diakses diamana pun dan kapan pun. Penggunan teknologi menjadi cara utama yang paling tepat dalam menerapkan pembelajaran daring (Assidiqi and Sumarni 2020). Dalam penggunaan pembeajaran daring masih banyak tenaga pendidik menggunakan layanan aplikasi via WhatsApp karena masih bingung menggunakan aplikasi yang tersedia dan masih awam, hal tersebut dianggap tidak efektif pada proses pembelajaran dikarenakan tidak bisa melakukan koneksi penghubungan video dalam jumlah yang banyak untuk mempertemukan peserta didik dan tenaga pengajar sehingga proses pembelajaran hanya sebatas pemberitahuan dan pengiriman materi (Haqien and Rahman 2020).

Hal tersebut membuah proses belajar dan mengajar memberikan dampak penurunan terhadap nilai akademik peserta didik, dampak lainnya yang terjadi pada masa pandemi membuat banyak peserta didik yang 
memilih berhenti melanjutkan pendidikannya dikarenakan proses pembelajaran membuat banyak peserta didik bingung, sehingga perlu pemberian bekal ilmu kepada para tenaga pendidik dalam membuat efektifitas pembelajaran daring .

Untuk meningkatkan efektifitas pembelajaran daring dapat digunakan menggunakan software Zoom dan Google Meet, kedua software ini sama-sama gratis dan mulai dari pendaftaran sampai penggunaannya juga sangat mudah dan masing-maisng software memiliki kelebihan dan keunggulan tersendiri. Penggunaan software ini sudah banyak diakses oleh banyak pengguna dan terbukti mampu dan efektif sebagai alat yang mendukung proses pembelajaran daring.

Sesuai pada penelitian terdahulu penggunaan software Zoom diakukan untuk membantu pembelajaran secara daring yang diterapkan pada Universitas wilayah DKI Jakarta dan depok dan hasil dalam penelitian memperlihatkan kemudahan dalam penggunaan aplikasi tersebut sangat membantu dalam berbagai bidang pekerjaan dalam dunia pendidikan, setiap pembelajaran yang diberikan menjadi lebih optimal dan membuat para peserta didik menjadi mendapat keuntungan dan kemudahal dalam proses pembelajaran (Assidiqi and Sumarni 2020). Penelitian terdahulu memperlihatkan penggunaan google meet sangat membantu dalam menjalankan banyak kegiatan terutaman dalam keberlangsungan pendidikan dan pelajaran dan menjadi infrastruktur utama dalam kegiatan belajar dan mengajar, flatform yang disediakan mudah dipahami dan dapat diakses secara universal(Haqien and Rahman 2020). Penelitian lainnya memperlihatkan keunggulan dalam penggunaan aplikasi zoom dapat meningkatkan proses pembelajaran dikarenakan fitur yang dilimiki zoom memungkinkan dalam merekam kegiatan untuk menjadi bahan pengajaran secara berulang, meningkatkan kemampuan dan pengetahuan peserta didik dan banyak keuntungan lainnya (Wood 2020). Peneltian terdahulu lainnya memperlihatkan google meet memiliki keunggulan terhadap limit waktu yang lebih dan dapat digunakan dengan nyaman, google meet dapat digunakan dalam mengadakan kegiatan ujian maupun interview test tanpa tatap muka langsung dalam mendukung kegiatan pemerintah dalam memutus tali penyebaran virus covid-19 pada masa pandemi(Plantin et al. 2018).

Berdasarkan gagasan dan permasalahan yang terjadi, dilakukan kegiatan pemberian transfer ilmu dalam menggunakan software Zoom dan Goole Meet dalam upaya meningkatkan efektifitas pembelajaran daring, kegiatan dilakukan dalam bentuk menyediakan workshop. Pelatihan akan membentuk kelompok dan grup pengajaran secara menyeluruh agar proses pemberian ilmu pengetahuan lebih merata dan tepat.

\section{METODE PELAKSANAAN}

Dalam metode pelaksanaan tahapan harus dirancang agar tetap berjalan sesuai dengan target pembuatan kegiatan workshop berjalan dengan baik dan terhindar dari beberapa kegiatan yang tidak diinginkan, adapun tahapan dalam metode pelaksanaan sebagai berikut ini:

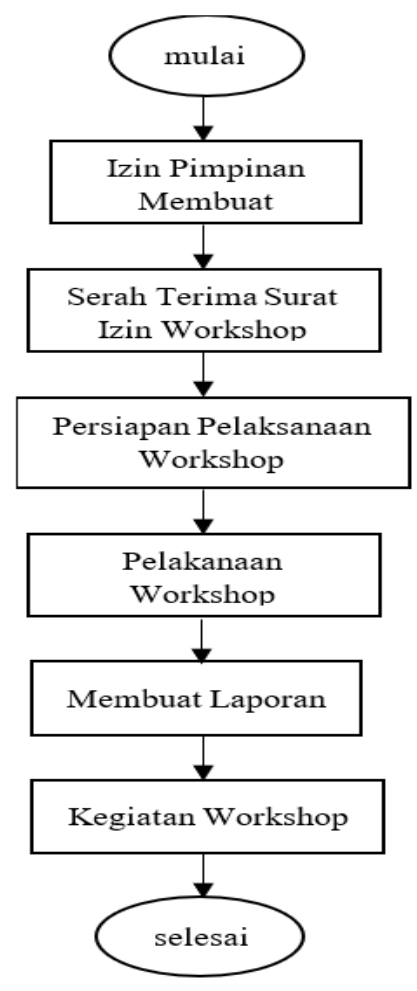

Gambar 1. Pelaksanaan Kegiatan 


\section{Journal of Social Responsibility Projects by Higher Education Forum}

Vol 2, No 2, November 2021, Page 94-97

ISSN 2723-1674 (Media Online)

\subsection{Tahapan Persiapan}

Persipan yang dilakukan untuk dapat menyelenggarakan workshop pelatihan penggunaan software sebagai berikut:

a. Membuat surat izin dalam rangka meminta persetujuan pengadaan workshop pada perguruan tinggi Hikmatul Fadhillah.

b. Membuat persiapan terhadap daya tamping lokasi dan jumlah audience yang bersedia ikut pelatihan

c. Menentukan tempat pelatihan

d. Melakukan persiapan terhadap alat-alat pendukung dalam

\subsection{Tahapan Pelaksanaan}

Tahapan yang dilakukan dalam pelaksanaan adalah sebagai berikut ini:

a. Pelaksanaan

Dalam tahapan pelaksanaan ini menjalankan pelatihan sesuai dengan tempat dan waktu, jumlah peserta audience yang telah ditentukan dan disepakati sebelumnya.

b. Evaluasi

Tahapan evaluasi akan dilakukan jika adanya kendala maupun hal-hal yang masih perlu perbaiki dalam memberikan ilmu pengetahuan terhadap peserta atau audience yang ikut serta dalam workshop.

c. Dokumentasi

Dokumentasi dilakukan untuk menunjukan kegiatan telah dilaksanakan dengan baik, dalam dokumentasi dapat berupa fie video, foto, dokumen dan lain-lainnya.

\section{HASIL DAN PEMBAHASAN}

Kegiatan dalam meningkatkan efektifitas pembelajaran daring menggunakan software zoom dan google meet memberikan peluang dan keuntungan terhadap peserta didik dan tenaga pendidik, setiap kegiatan dilakukan berdasarkan ketentuan yang telah diatur dalam persiapan dan pelaksanaan pembuatan workshop dan tetap mengikuti peraturan terhadap protocol kesehatan yang berlaku.

\subsection{Pelaksanaan Kegiatan}

Pelaksanaan dilakukan pada aula ruang pertemuan II pada perguruan tinggi Hikmatul Fadhilah pada bulan September 7-8 dilakukan pada pukul 08: 15 - 16:00 WIB dengan jumlah peserta pelatihan sebanyak 48 orang dengan judul workshop pelatihan "Optimalisasi Penggunaan Software Zoom Dan Google Meet Dalam Meningkatkan Efektifitas Pembelajaran Daring”.

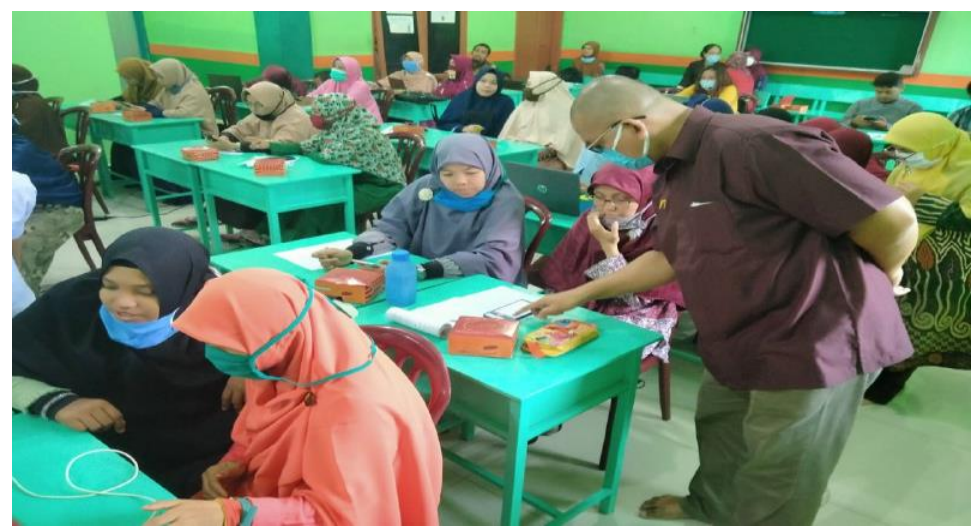

Gambar 2. Dokumentasi Kegiatan

\subsection{Materi Kegiatan}

Kegiatan menjelaskan tentang manfaat masing-masing software, setiap kegiatan dalam penggunaan software baik zoom maupun google meet yang memiliki beberapa kesamaan dan beberapa perbedaan tetapi sama-sama sangat efektif dalam mendukung dan membantu dalam proses pembelajaran daring. Adapun kemudahan dalam masingmasing dan cara menggunakan nya adalah sebagai berikut ini:

1. Zoom could Meeting

Dalam penggunaan zoom could meeting dilakukan sebagai berikut ini:

a. dengan menyediakan software tersebut, dapat diakses dari laptop atau via desktop maupun mobile atau smartphone ada bainya aplikasi ini di undug atau dipasang agar lebih leluasa untuk diakses.

b. Lakukan pendaftaran dengan akun gmail anda atau membuat akun zoom baru 


\section{Journal of Social Responsibility Projects by Higher Education Forum}

Vol 2, No 2, November 2021, Page 94-97

ISSN 2723-1674 (Media Online)

c. jika melakukan pertemuan atau meeting dapat mengikuti dengan joint dan memasukan kode atau Id untuk masuk kedalam forum yang tersedia atau dapat merambatkan link.

d. Jika ingin membuat forum pembelajaran tersendiri maka dapat membuat start meeting dan user dapat menentukan password atau id yang akan digunakan atau menerima id yang telah disediakan oleh zoom.

e. Dalam penggunaan zoom meeting terdapat layanan record atau merekam seluruh kegiatan pembelajaran, agar mudah di akses orang lain.

f. Terdapat firut share layar dan control terhadap mute voice audience dan lain-lainnya.

g. Dalam penggunaan zoom meeting dapat mengatur schedule untuk membuat pertemuan dalam sebuah forum online.

h. Dapat merubah background dalam setiap pertemuan sesuai dengan tema.

2. Google Meet

Penggunaan google meet sasma hal nya dengan menggunakan dan proses pendaftaran menggunakan zoom could meeting adapun tahapan penggunaan sebagai berikut ini:

a. Download aplikasi baik pada desktop atau smartphone tergantung menggunakan yang mana.

b. Lakukan daftar atau login terhadap aplikasi "biasanya akan langsung terhubung dengan gmail karena merupakan produk dari google juga"

c. Pada google meet dapat langsung membuat forum pertemuan dengan klik "rapat baru" atau jika ingin masuk dan bergabung pada suatu forum pembelajaran dapat bergabung menggunakan kode.

d. Pada google meet menyediakan fitur dalam membagi layar kerja.

\subsection{Evaluasi}

Evaluasi dilakukan ketika penjelasan dan penyampaian materi telah dilaksanakan secara menyeluruh, evaluasi dilakukan juga setelah dilakukan proses praktek terhadap penggunaan software Zoom Could Meeting dan Google Meet, ketika peserta kurang mengerti dalam proses penggunaan aplikasi akan dilakukan pembagian kelompok untuk membantu meratakan dalam penyaluran informasi agar mempermudah memberikan pemahamn terhadap penggunaan seluruh software yang ingin diterapkan.

\section{KESIMPULAN}

Pelatihan yang diberikan oleh dosen-dosen dalam memenuhi tugas pengabdian sebagai bentuk penyaluran ilmu pengetahuan yang telah dimiliki kepada tenaga pendidik lainnya sangat membantu dalam masa pandemi pembelajaran online, penggunaan teknologi semakin marah dan mudah diakses melalui pembelajaran workshop peningkatan efektifitas pembeajaran daring menggunakan software zoom dan google meet. Aplikasi yang memiliki nama yang cukup terkenal dan proses tahapan penggunaan yang mudah dipahami membuat prose pembelajaran mudah diterima. Penerapan software sangat membantu dan memberikan keuntungan sendiri terhadap peserta didik dan tenaga pendidik.

\section{DAFTAR PUSTAKA}

Assidiqi, M H, and W Sumarni. 2020. "Pemanfaatan Platform Digital Di Masa Pandemi Covid-19.” Prosiding Seminar Nasional ..., 298-303. https://proceeding.unnes.ac.id/index.php/snpasca/article/download/601/519.

Haqien, Danin, and Aqiilah Afiifadiyah Rahman. 2020. "Pemanfaatan Zoom Meeting Untuk Proses Pembelajaran Pada Masa Pandemi Covid-19." SAP (Susunan Artikel Pendidikan) 5 (1). https://doi.org/10.30998/sap.v5i1.6511.

Plantin, Jean Christophe, Carl Lagoze, Paul N. Edwards, and Christian Sandvig. 2018. "Infrastructure Studies Meet Platform Studies in the Age of Google and Facebook." New Media and Society 20 (1): $293-310$. https://doi.org/10.1177/1461444816661553.

Syarifuddin, Fahmi, Muhammad Misdram, Anang Aris Widodo, Program Studi Informatika, and Universitas Merdeka Pasuruan. 2020. “KLASIFIKASI DATA SET VIRUS CORONA MENGGUNAKAN” 12 (2): 46-52.

Wood, David A. 2020. "Predicting Porosity, Permeability and Water Saturation Applying an Optimized Nearest-Neighbour, Machine-Learning and Data-Mining Network of Well-Log Data." Journal of Petroleum Science and Engineering 184 (January): 106587. https://doi.org/10.1016/j.petrol.2019.106587.

Yunus, Nur Rohim, and Annissa Rezki. 2020. "Kebijakan Pemberlakuan Lock Down Sebagai Antisipasi Penyebaran Corona Virus Covid-19." SALAM: Jurnal Sosial Dan Budaya Syar-I 7 (3). https://doi.org/10.15408/sjsbs.v7i3.15083. 